\title{
WOMAN EXPLOITATION IN WARKOP DKI POSTER FILM
}

\author{
Asidigisianti Surya Patria $^{1 *}$; Nova Kristiana ${ }^{2}$; Hendro Aryanto ${ }^{3}$ \\ ${ }^{1,2,3}$ Design Department, Faculty of Language and Art, Universitas Negeri Surabaya \\ Jl. Lidah Wetan, Lakarsantri, Kota SBY, Jawa Timur 60213, Indonesia \\ 1asidigisiantipatria@unesa.ac.id; ${ }^{2}$ novakristiana@unesa.ac.id; ${ }^{3}$ hendroaryanto@unesa.ac.id
}

Received: $22^{\text {nd }}$ October 2020/ Revised: $15^{\text {th }}$ November 2020/ Accepted: $23^{\text {rd }}$ November 2020

How to Cite: Patria, A. S., Kristiana, N., \& Aryanto, H. (2021). Woman exploitation in Warkop DKI poster film. Humaniora, 12(1), 13-19. https://doi.org/10.21512/humaniora.v12i1.6756

\begin{abstract}
The research aimed to determine a representation of women in the poster of Warkop DKI comedy film (Dono, Kasino, Indro) in 1980-1989 from a woman point of view. The involvement of women as models in the film poster media was not yet clear in terms of their roles; however, women could be used more as commodities of capitalism to reap profits. In the patriarchal rule, men were assumed to be created as culture-making in the other women were subordinated. The research applied a descriptive qualitative methods by collecting data using documentation techniques. The collected data was reducted, presented, and concluded. Roland Barthes'semiotic theory was used to analyze poster design elements that contained the exploitation of the female body. The research results find that (1) women in the film poster media are only subordinated to the poster to attract men, potential viewers. (2) Film posters show sexual exploitation and eroticism that is made into a high-selling and quite promising commodification.
\end{abstract}

Keywords: women exploitation, women subordination, women stereotyping, film posters

\section{INTRODUCTION}

Since Indonesia's political changes that supported the New Order, women's organizations that were originally their true forum for expressing their aspirations disappeared. These organizations were no longer formed based on the interests of equal rights. In the 1980 s, consideration and politics in the film industry created a diegetic space for women. In Indonesia, the film industry in 1980 was unable to compete with the importance of legal and pirated videos/films (Ibrahim, 1997). This is a new representation of women who can be used as an attraction for potential national film viewers as an effort to fight pirated videos/ films. When peeking at the camera, men are looking for sexual vibrations with a point of view that is sexually appropriate. They write screenplays following his male instincts. Women are still in the trap of masculinity in society, which tends to see men as main actors and women as complementary roles.

Women are a source of happiness, pleasure, intimacy, social status, and art. This group glorifies sex as a gift from God Almighty to humans. Sex is seen as a source of inner calm, a source of inspiration, and even one of the ultimate goals of human struggle. On the other hand, they accuse sex as both the object and the subject of the source of calamity for women themselves. In radical feminist thought, it considers gender as the source of the problem of sexism (social discrimination based on sex) and patriarchal ideology. This thinking accuses men biologically and politically of controlling women's bodies because men are physically stronger to treat women as their sex objects (Burhan, 2007). The female body as an object of porn has long been a polemic in almost all societies due to the existence of two poles in assessing the human body (especially women) as a sex object.

Advertising is a mass communication tool, which now tends to implement gender discourses that challenge gender injustice biases. The openness of embedding an image into advertising communication will be polysemic because it opens up opportunities for more than one interpretation, not only to offer one use without other nuances that add value to the appeal of the visualization. In simple terms, advertising is defined as a message that offers a product aimed at the public through a medium to reach new potential customers (Kotler \& Keller, 2010). 
A movie poster is used for advertising a film. Studios often print several posters that vary in size and content depending on the domestic and international market. These posters usually contain visuals and text (Rustan, 2008). Usually, film posters often feature photos of the main actors in the film title. Before the 1970s, film posters were created in the form of hand-painted illustrations in enormous sizes (Patria, Kristiana, \& Aryanto, 2019a).

The legendary comedy film is Warkop DKI (Warung Kopi Dono, Kasino, Indro). Warkop DKI is one of the strongest influences for Indonesian cinema, especially for comedy genre films. Warkop DKI films have a typical slapstick comedy script formula. However, they are also combined with intellectual comedy that intelligently criticizes political situations even though more or less sensual scenes are shown in some film titles (Hartono, 2015). The humor language technique is most widely used in Warkop DKI films because of the background of members of the Warkop $D K I$ group themselves as radio broadcasters with the concept of a program in the form of jokes, which makes Warkop DKI is stronger in throwing humor through their stories.

Comedy films are a genre of film in which the main emphasis is on humor. A film in this traditional style has a happy ending (black comedy exception). One of the oldest genres in film, the first few silent films are comedy. Unlike other film genres, comedy places more focus on the individual star with many former comedians standing transitioning to the film industry due to their popularity. In the early 1980 s, the comedy film Warkop DKI with its Warkop angels began to be demanded to appear sexy to boost the sluggish Indonesian film industry due to the economic and political turmoil at that time, as well as additional films from abroad that entered Indonesia. This makes the producers place women into commodity grinding machines of capitalism. The women who are shown must be beautiful and sexy to get instant success and popularity so that they can enjoy a hedonistic life. Women are only used as objects by men. Men create a patriarchal ideology as the basis for oppression, which is a sexuality hierarchy system in which men have superior power and privilege to women (Benedicta, 2011). However, if this is the case, it is clear that patriarchal culture plays a very important role and influence. Patriarchy is also closely related to the power of women's bodies. Patriarchal power, where women are only made the second human in all respects, includes in the context of sexuality. However, from the viewpoint of a progressive approach, pornography is a representation of the dehumanization process of women who are positioned as sexual objects, objects, and commodities. Humiliation, violence, and abuse often present themselves in destructive scenarios.

Often in the posters of this film, Warkop angels are shown to be an attraction as well as what the potential audience has been waiting for. Before the film is screened, there is usually a mobile car shouting the film schedule, title, artists in the film that will be screened, and spreading leaflets in the form of media posters to be affixed in strategic places to be seen and read.

In modern marketing strategies, the existence of advertising has become an inevitable demand for a product being offered to have a place in the hearts of the public. To gain influence and trusted, the advertiser put women's illustrations or pictures (Kotler \& Keller, 2010). Poster design as an advertising medium is responsible for conveying messages in an informative, persuasive, and attractive manner (Dewojati, 2009). A film poster normally contains images of the main actors or a scene or a collage of several film scenes with text. The textual information on film posters usually contains the title of the film in large lettering, names of the main actors, director, producer, music director, story writer, and the date of releases (Goswami, 2017).

Meanwhile, film posters are made to popularize a film produced in the film industry (Rustan, 2008). In the era of the $80 \mathrm{~s}$, beauty was changed to a new standard. Those who are called beautiful are women who have smooth and soft skin. The development of the new beauty standards is impressive because it makes women follow advertising recommendations (Rahardjo, Hagijanto, \& Maer, 2016). For the seduction of these advertisements, the public has embraced new beauty standards. So far, the film posters featured in the comedy film Warkop DKI have always been enlivened by beautiful, sexy girls with erotic poses that have proven to be more successful in captivating the audience at that time. They consisted of artists who were excellent and were so adored by men at that time. Their roles are various, such as being students, college friends, to servants. Therefore, the research aims to describe the image of women in the poster of the comedy film Warkop DKI at 1980-1989 from a gender perspective in the woman as subordinate and woman stereotyping.

\section{METHODS}

The research uses a qualitative descriptive research method with the Warkop DKI comedy film posters from 1980-1989 as the object. The film posters are selected by the purposive sampling method which is a nonrandom sampling technique selected based on specific characteristics that correspond to the purpose of the research. The film posters are Gengsi Dong (1980), Dongkrak Antik (1982), Maju Kena Mundur Kena (1983), Depan Bisa Belakang Bisa (1987), and Makin Lama Makin Asyik (1987).

The research identifies and describes woman images, defined as visual symbols. These markers are then analyzed using a visual semiotics approach. For data collection, it uses documentation and observation techniques. The research applies a semiotic analysis technique of Roland Barthes to determine the exploitation of the female body as a manipulation tool (Woodrich, 2018), which is intended as a sign of certain stereotypical symbols on the posters. For Barthes, the 
important factor in connotation is the marking in the first order. The first order marker is a connotation. He emphasizes that at least in the photo, the difference between denotation and connotation becomes clear. The connotation is a human part of the process, which includes the selection of what is included in the frame (frame), focus, shutter, camera point of view, and so on (Fiske, 2007). In Figure 1, it can be seen that in the second-order, the sign system from the first order is inserted into the cultural value system.

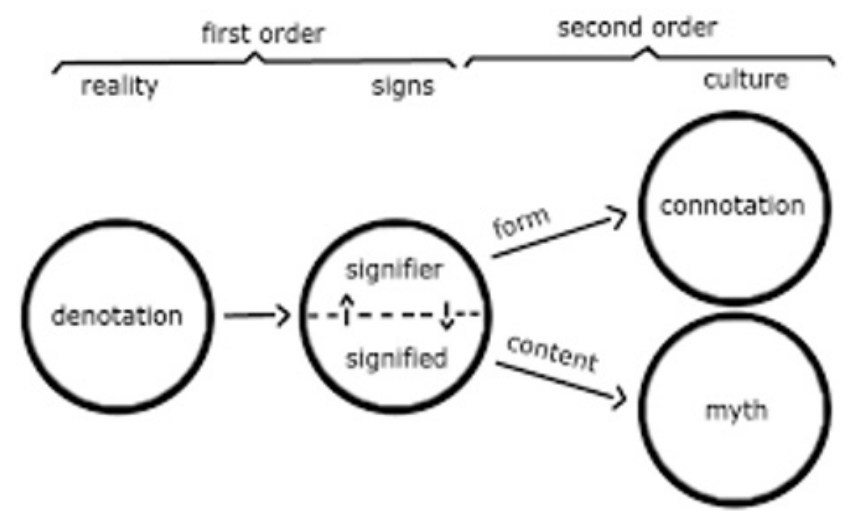

Figure 1 Two Orders of Sign Barthes (Source: John Fiske, 2007)

\section{RESULTS AND DISCUSSIONS}

Posters are the simplest promotional media consisting of one unfolded sheet printed on a twodimensional face. Media posters are created as a communication for the public in the open space (Sosroyudho, 2010). The film poster is purposed to promote the film which tells the story of the film so that the target audience is interested in watching the film. The illustrations of the poster film usually become the summary of the film. The illustration can be both the drawing and the photo (Rustan, 2008). Illustrations of woman's sexuality are found in film posters for comedies, thrillers, sexploitation, and horror films. The central trait of the sexual woman is consistently depicted in minimal clothing (Woodrich, 2016). Sexy and attractive women can be the main attraction for the poster film so that the audiences would see the movie (Aryanto, 2014). In the comedy film posters, all the actors are smiley and happy face (Patria, Kristiana, \& Aryanto, 2019a).

Female actresses who play roles in Warkop DKI films include Lidya Kandou, a senior actress who is still actively playing in soap operas and on the big screen. She has played four times in Warkop DKI films, Maju Kena Mundur Kena (1983), Pokoknya Beres (1983), Tahu Diri Dong (1984), and Kesempatan Dalam Kesempitan (1985). Then, Ira Wibowo successfully plays in three films of Warkop DKI in the 80s, namely Itu Bisa Diatur (1984), Gantian Dong (1985), and Jodoh Boleh Diatur (1988). Her role that Warkop $D K I$ fans remember the most is when she becomes a matchmaker in the last film. She is one of the most active and senior sexy actresses to enliven the film Warkop DKI. There have been nine-film titles that she has starred in, including Pintar-Pintar Bodoh (1980), Manusia Enam Juta Dollar (1981), Pokoknya Beres (1983), and Atas Boleh Bawah Boleh (1986). Her Caucasian face as the main character has made Warkop DKI include her in their three films, Malu Malu Mau (1988), Mana Bisa Tahan (1990), Pasti Tahan (1991). Camelia Malik also plays in Gengsi Dong (1980).

Figure 2 shows the film poster of Gengsi Dong, the 1980 Warkop DKI film. It is the third highest-grossing film of 1980 in Jakarta with 230.555 admissions according to Perfin (National Film Distributors Association - filmindonesia.or.id). The denotation of this film poster is Camelia Malik (singer) as the main attraction, who is beautiful and sexy. She is shown smiling dominantly, wearing a dress with a slit up to her upper thigh while holding the mic with her left hand at her waist. On the other hand, the men emerge under the woman driving an old car. At the same time, the connotation of it is the woman that is showed as the main attraction. She seems inviting, alluring, and enchanting to those who see it. The men smile and seem happy. The myth of this poster is the pleasure under the rules of patriarchy, where women are only used as a second man in all respects, including in the context of sexuality. In the patriarchal pleasure method, women are only made objects by men. Women are only used as 'cherry on tops' to attract potential viewers and raise ratings.

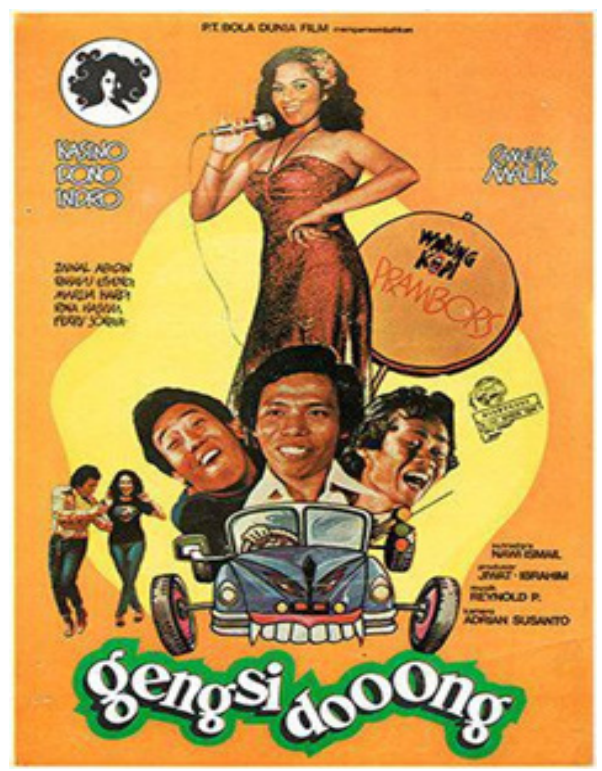

Figure 2 Gengsi Dong Film Poster

Dongkrak Antik is a 1983 Warkop DKI film. The poster of this film can be seen in Figure 3. It is the second highest-grossing film of 1982 in Jakarta, with 331.963 viewers according to Perfin (filmindonesia. or.id).

The denotation in this film poster film (Figure 3) is a sexy woman on the knee of a man who is helping 
him to jack a car in a fully erotic pose. His left leg is raised in the position of a jack stalk. The connotation is an attraction. The pose of a woman leads to sexuality, lust, makes people curious, eager to see, and even tends to do. If the man and woman position is connected to the film title, it means that this position of lifting the car using the jack. The myth is a real sexual symbol that plays with the beholder's desires, and promises will show even though they are generally outside the discourse of sexuality. Patriarchal culture plays a role and is very influential. Patriarchy is also closely related to the power of women's bodies. Patriarchal culture is believed to contribute to the work that is degrading women, in this case, the headline or title of the movie posters and portraits of a sexy woman who approaches porn action. The fundamental relationship between the dualistic world view and women's objectification has become a central tenet in feminist theory over 30 years ago.

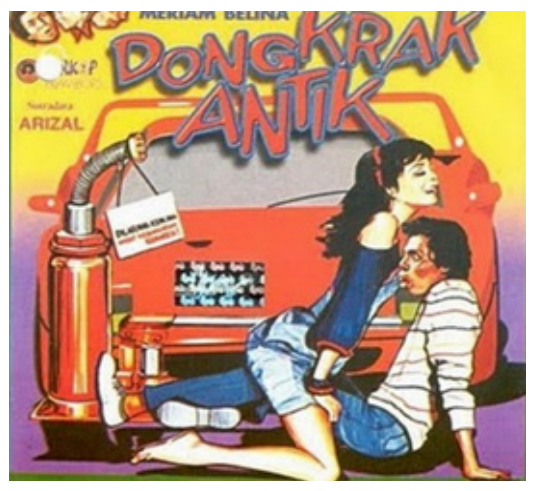

Figure 3 Dongkrak Antik Film Poster

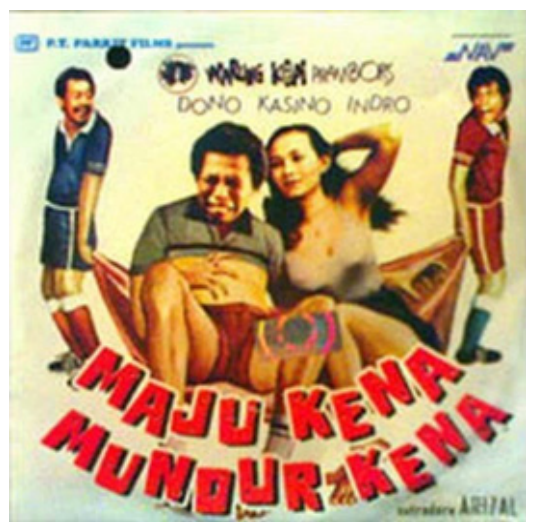

Figure 4 Maju Kena Mundur Kena Film Poster

Figure 4 shows Maju Kena Mundur Kena poster film. It is a 1983 Warkop DKI film. The denotation is a beautiful and sexy woman that wears an undershirt until the part of her breasts posing while parting her hair with her left hand and sitting showing her thighs. Dono also shows his thigh. The connotation is an attraction, an offer, a solicitation, a spoiled, passionate, and erotic attitude. The myth of it is the women's bodies deserve to be obeyed so that it is not to exceed the limits of male authority. The woman seems to be pleased, happy, and proud when she is famous through the mass media. She does not realize that her body is being the medium of the scandal basis of the pornographic authorization. Besides, pornography is a metaphor as well as a tool to maintain the dominance of men over women's sexuality.

The next film poster is Depan Bisa Belakang Bisa, a 1987 Warkop DKI film that can be seen in Figure 5. According to Perfin data, it is the second most popular film in Jakarta in 1987, with 327.039 viewers (filmindonesia.or.id). This film poster's denotation is a beautiful woman sitting with her legs stretched out wearing a party dress with a slit down to her upper thigh, and her left-hand brushes her hair with a smiling face. The connotation is interpreted as alluring, seducing, inviting, passionate, lust, and erotic. While the myth is in a capitalist industrial society, pornography is packaged in such a way and is mass-marketed; of course, the goal is to achieve maximum profit. Women in the industry are placed as a commodity that is exploited. This is an emphatic depiction of female sexuality through images.

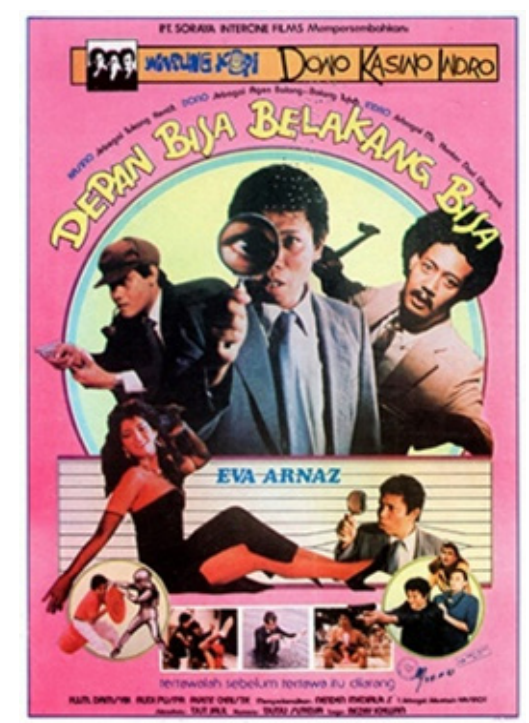

Figure 5 Depan Bisa Belakang Bisa Film Poster

The next poster film is Makin Lama Makin Asyik, a 1983 Warkop DKI film that can be seen in Figure 6. According to Perfin data, this is the first most popular film in Jakarta in 1987, with 504.220 viewers (filmindonesia.or.id).

The denotation film poster in Figure 6 is a beautiful woman, sitting on a man's back, wearing a sleeveless shirt, sexy, holding two bananas in her right and left hands with her eyes and smiling face. The connotation is passionate, strong, challenging men, but still feminine and seductive eyes. Banana can be represented by male genitalia (Woodrich, 2016). The myth is the commodification of the body that is exposed in the media is still not visible clearly. It clearly contains pornographic elements that exist in the world of the market industry because it has blended 
and become public consumption in their daily lives, so he is not aware of it. Women are usually proud when they are well known through electronic and printed mass media that makes them unaware that this is a form of obedience to the body through the media with the basic scandal of power in every woman's body that contains pornographic elements. Even though women are in the public sphere, there is still an extension or participation of men's power. The mass media can be used to convey certain messages, as well as related to issues of pornography and freedom of expression. The name of the mass media is also a reflection of the opinion of some people. So that what is published in the media, in this case, the film poster, is what is believed by the public regardless of what is happening behind it. The involvement of patriarchal culture is not only in the private sphere but has also entered the public sphere.

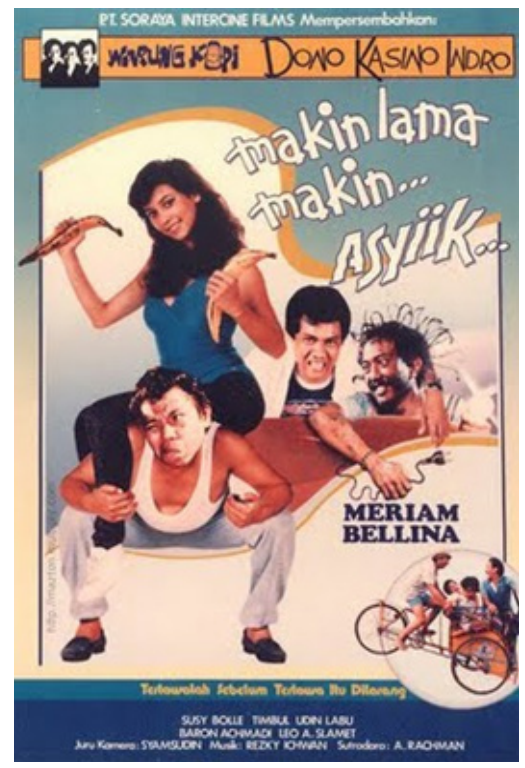

Figure 6 Makin Lama Makin Asyik

The differences between men and women are essentially the result of socio-cultural constructions, resulting in different roles and tasks. This difference causes women always to be left behind and neglected by their roles and contributions in family, social, national, and state life. Social construction places women and men in class differences. Men are identified with the bourgeoisie and women as proletarians (Karim, 2014; Wandi, 2015). These five posters show that women in the film industry are placed as exploited commodities. Men are the capitalist constructed stereotyping of women's bodies as the commodity that sold.

Sexual exploitation of women is seen in the poster table for the comedy film Warkop DKI above. All the posters displayed (Figure 2-6) show beautiful women in sexy clothes and highlight women's body such as the chest, thighs, and buttocks. Body language is more solicitous, passionate, lustful, and erotic. Women are identical to being happy and proud when they are well known and often exposed by the media. They do not realize that it is a form of obedience to the body through the media with the scandalous power base on every woman's body that contains pornographic elements (Endang, 2016). According to Dworkin (in Rueda, Rodriguez, \& Watkins, 2007), pornography is not biological but cultural and open to change. The media has a very powerful influence, especially in the industrial world, to smoothing the vision and mission of groups or groups and even individuals.

Capitalists cheat to make a profit by placing or exposing sexy and erotic women's bodies on the walls of the media. Women's bodies that are very attractive from head to toe become one of the factors that make them the commodities of the owners of capital. They make women with sexy bodies, beautiful faces, and erotic poses the object of film commercials (Endang, 2016). Eroticism is a commodity that has a high selling value and is quite promising. Eroticism is also deliberately created and allowed to roll in the middle of the development of mass media to influence people's perceptions so that people will perceive sexy and eroticism as normal, even though it will lead to pornography (Rueda, Rodriguez, \& Watkins, 2007).

A culture that peddles dreams and hallucination makes it easier for women to fall into the desire to achieve instant success. Women are like objects consumed by many people and become objects of sex (Endang, 2016). Women are commodities in the grinding machine of the capitalist system. They have to perform optimally even if they have to pose 'challengingly'. Woman image is seen as the realization of the advertising motto 'sex sells', and male viewers are drawn in through female sexuality that is simultaneously depicted as alluring and yet undesirable. The woman is shown as being animalistic or insane rather than as a rational person with the agency (Woodrich, 2016). Women are visualized as sex objects (Patria, Kristiana, \& Aryanto, 2019b). Manifestations of stereotyping cannot be separated because they influence each other. Neither one of its manifestations is more important nor more essential than the other. The media poster for Indonesian films in the 1980s above is a form of economic marginalization against women, which occurs because of women's negative labeling. It also plays a role in creating insignificant assumptions, violence against women, which in the end is socialized in beliefs, the ideology, and the vision of the women themselves (Aryanto, Patria, \& Kristiana, 2019).

Dworkin (in Gamman \& Marshment, 2017) has tried to connect directly between pornography and male violence against women. He has said that people who know about men use pornography as a tool to instill and herald the power of men. According to him, in all types of pornography, objects that are made objects by male cruelty. Becoming sexual objects are shamed and humiliated. These women in the poster are called bomb sex in that era, and some still are carried till now (Matanasi, 2016). Patriarchal ideology in Indonesian films is used as where women are 
made objects in this film. This indirectly legalizes the construction of women as weak beings and can only be physically exposed. Then, in economic terms, the mass media, especially film, is a business institution that wants only profit (Ayun, 2015). These patriarchal constructs reflected in the film will affect how society views sex and gender in real life. It results in sex being the only thing that defines a woman's role in society (Sutanto, 2020).

\section{CONCLUSIONS}

In the early 1980 s, the film industry was sluggish. Warkop DKI is a comedy genre film that presents another form from the previous year's films. Another form is showing beautiful women with erotic and sexy poses adorning the illustrations/visuals on the poster of the comedy film Warkop DKI in each episode. Producers deliberately use female as an object with beautiful and sexy criteria solely for their business advantage. The stereotypes that arise are various opinions that point to women as the subjects responsible for porn media. Around the beginning of 2000, there was a shift in Indonesia's film genre from comedy to horror, but what was sold was the same, still around the exposed chest and thighs. The emergence of the horror film genre and its film poster advertisements also take advantage of sexuality and eroticism as an attraction to attract potential viewers. Capitalist seems like running out of ideas that always take advantage of women as victims of patriarchal power. Women are only made second to all things.

\section{ACKNOWLEDGMENTS}

This research was supported granted by DRPM (Direktorat Riset dan Pengabdian Masyarakat) Kementrian RISTEK-BRIN (Riset dan Teknologi/ Badan Riset dan Inovasi Nasional) and fully supported by LPPM (Institution of Research and Community Service) Universitas Negeri Surabaya (UNESA) and based on contract number: No. B/21835/UN38.9/ LK.04.00/2020, 29 th March 2020. We thank our reviewers who provided insight and expertise that greatly assisted the research, although they may not agree with all of the interpretations/conclusions of this paper. We thank to blind reviewers for comments that greatly improved the manuscript.

\section{REFERENCES}

Aryanto, H. (2014). Eksploitasi perempuan dalam media poster film horor di Indonesia sebagai bentuk ketidakadilan gender. Dimensi, 11(1), 43-54.

Aryanto, H., Patria, A. S., \& Kristiana, N. (2019). Perempuan dalam media poster film Indonesia di era tahun 1970-an. In Seminar Nasional Seni dan Desain 2019. Surabaya, Indonesia. pp. 201-204.

Ayun, P. Q. (2015). Sensualitas dan tubuh perempuan dalam film-film horor di Indonesia (Kajian Ekonomi Politik Media). Simbolika, 1(1), 16-23. https://doi. org/10.31289/simbollika.v1i1.46.

Benedicta, G. D. (2011). Dinamika otonomi tubuh perempuan: Antara kuasa dan negosiasi atas tubuh. Masyarakat: Jurnal Sosiologi, 16(2), 141-156. https://doi.org/10.7454/mjs.v16i2.4963.

Burhan, B. (2007). Sosiologi komunikasi: Teori, paradigma, dan diskursus teknologi komunikasi di masyarakat. Jakarta: Kencana Pradana Media Grup.

Dewojati, R. K. W. (2009). Desain grafis sebagai media ungkap periklanan. Imaji: Jurnal Seni dan Pendidikan Seni, 7(2), 175-182. https://doi. org/10.21831/imaji.v7i2.6633.

Endang, K. (2016). Tubuh perempuan yang dipatuhkan. Retreieved from https://www.jurnalperempuan. org/wacana-feminis/tubuh-perempuan-yangdipatuhkan.

Fiske, J. (2007). Cultural and communication studies. Yogyakarta: Jalasutra.

Gamman, L., \& Marshment, M. (2017). Tatapan perempuan; Perempuan sebagai budaya populer. Yogyakarta: Jalasutra.

Goswami, M. P. (2017). Bollywood film posters: A study of changing trends. Journal of Content, Community, and Communication, 6(3), 78-84.

Hartono, L. (2015). Teknik humor dalam film Warkop DKI. Jurnal E-Komunikasi, 3(1), 1-10.

Ibrahim, I. S. (1997). Ecstasy gaya hidup: Kebudayaan pop dalam masyarakat komoditas Indonesia. Bandung: Mizan Pustaka.

Karim, A. (2014). Feminisme: Sebuah model penelitian kualitatif. SAWWA: Jurnal Studi Gender, 10(1), 8398. https://doi.org/10.21580/sa.v10i1.643.

Kotler, P., \& Keller, K. L. (2010). Manajemen pemasaran. Jakarta: Erlangga.

Matanasi, P. (2016). Parade bom seks tanah air. Retrieved from https://tirto.id/parade-bom-seks-tanah-airbwsW

Patria, A. S., Kristiana, N., \& Aryanto, H. (2019a). Comedy film posters in the 70's era. Proceedings of the Social Science, Humanities, and Education Conference (SoSHEC). pp. 169-174. https://dx.doi.org/10.2991/ soshec-19.2019.37.

Patria, A. S., Kristiana, N., \& Aryanto, H. (2019b). Indonesian thriller film poster in the 70's era. E-Prosiding Pascasarjana, 1(1), 71-79.

Rahardjo, S., Hagijanto, A. D., \& Maer, B. D. A. (2016). Mitos kecantikan wanita Indonesia dalam iklan televisi produk Citra era tahun 1980-an, 1990-an, dan 2010-an. Jurnal DKV Adiwarna, 1(8), 1-14.

Rueda, M., Rodriguez, M., \& Watkins, S. A. (2007). Feminisme untuk pemula. Yogyakarta: Resist Book.

Rustan, S. (2008). Layout dasar dan penerapannya. Jakarta: Gramedia Pustaka Utama.

Sosroyudho, A. (2010). Tinjauan desain grafis. Yogyakarta: PT Concept Media.

Sutanto, S. M. (2020). Dekontruksi representasi perempuan pada poster film pahlawan super produksi Hollywood. Andharupa: Jurnal Desain Komunikasi Visual \& Multimedia, 6(1), 1-17. https://doi. 
org/10.33633/andharupa.v6i1.3234.

Wandi, G. (2015). Rekonstruksi maskulinitas: Menguak peran laki-laki dalam perjuangan keseteraam gender. Kafa'ah: Jurnal Ilmiah Kajian Gender, 2(5), 239255. http://dx.doi.org/10.15548/jk.v5i2.110.

Woodrich, C. A. (2016). Depictions of women in Suhartoera Indonesian film flyers (1966-1998). Indonesian Feminist Journal, 4(1), 38-50.

Woodrich, C. A. (2018). Representing Islam in Indonesian film advertising during the Suharto era (1966-1998) and reform era (1998-Present). Jurnal Komunikator, 10(2), 60-74. https://doi.org/10.18196/jkm.101006. 